\title{
Assessment of Some Geotechnical Properties of Nigerian Coastal Soil: A Case-Study of Port-Harcourt Beach Mud
}

\author{
${ }^{1 *}$ OWAMAH, HI; ${ }^{1}$ ATIPKO, E; ${ }^{1}$ UKALA, DC; ${ }^{2}$ APKAN, E \\ ${ }^{* 1}$ Department of Civil Engineering, Delta State University, PMB 1, Abraka, Oleh Campus, Nigeria \\ ${ }^{2}$ Department of Civil Engineering, Landmark University, Omu-Aran, Kwara State, Nigeria \\ *Email: owamah.hilary@gmail.com; hiowamah@delsu.edu.ng +2348035705814
}

\begin{abstract}
Soils naturally exhibit variable engineering properties and thus make the geotechnical characterization of soil for sustainable design and construction of infrastructure imperative. This study was undertaken to investigate the geotechnical properties of the underlying soils of the Port-Harcourt Beach Mud, Rivers State, Nigeria. Five boreholes namely $\mathrm{BH} 1, \mathrm{BH} 2, \mathrm{BH} 3, \mathrm{BH} 4$ and $\mathrm{BH} 5$ were drilled using hand auger at different depths of $300 \mathrm{~mm}, 350 \mathrm{~mm}, 400 \mathrm{~mm}, 450 \mathrm{~mm}$ and $500 \mathrm{~mm}$ respectively. Basic geotechnical tests were then performed on the samples in the laboratory to determine their properties. Results obtained showed that the area is underlain predominantly by poorly graded sands based on the Unified Soil Classification System (USCS). The soil material had an average Moisture Content of $71 \%$, Liquid Limit of $13 \%$, Plastic Limit of $11 \%$, Plasticity index (PI) of $2 \%$ and Hydraulic Conductivity (K) of $2.88 \times 10^{-1} \mathrm{~cm} / \mathrm{s}$. The high values of $\mathrm{K}$ show that the aquifer system in the area is prolific. The soil material however met the requirements of the Nigerian General Specifications for use as subgrade in the construction of roads.
\end{abstract}

DOI: https://dx.doi.org/10.4314/jasem.v22i2.13

Copyright: Copyright (C) 2018 Owamah et al. This is an open access article distributed under the Creative Commons Attribution License (CCL), which permits unrestricted use, distribution, and reproduction in any medium, provided the original work is properly cited

Dates: First received 18 November 2017; Received in revised form 03 December 2017; Accepted 17 January 2018

Keywords: geotechnical properties, hydraulic conductivity, California Bearing Ratio

Neglect of geotechnical investigation in the design of Civil Engineering projects in Nigeria had led to the collapse of many structures with its attendant effects on services provided by the structures and the Nigerian economy. Geotechnical site investigation is carried out to estimate properties of rock and soil, and for underground stratigraphic analysis of geotechnical systems (Clayton et al., 1995; Mayne et al., 2002). Geotechnical site investigation comprises six stages viz; desk-study, site reconnaissance, in-situ investigation, laboratory testing, analysis and interpretation of site observation data, and inferring soil and rock properties and underground stratigraphy (Wang et al., 2016; Cao et al., 2016). Frequent cases of structural failure in the Nigerian coastal cities such as Lagos, have become a source of worry to the populace; hence the need for a good understanding of the geotechnical properties of subsurface soils in these areas (Startrite, 2000).

Soil is the un-cemented aggregate of mineral grains and decayed organic matter (solid particles) with liquid and gas in the empty spaces between the solid particles (Das, 2013). Mud sediment (which is a soil type) is refered to as a set of loose particles of clay, silt and sand, formed from the erosion of rocks and soils (Life, 2002; Dubois et al., 2011). Geotechnical properties of mud sediment are like those of coastal mud deposits in many ways such as in strength, viscosity and density (Calliari and Fachin, 1993; Holland et al., 2009; Dias and Alves, 2009). The need for adequate understanding of the geotechnical properties of subsoil cannot be overemphasized (Youdeowei and Nwankwoala, 2011), in ensuring that the effects of engineering projects on the environment are well evaluated (Nwankwoala et al., 2009). Geotechnical characterization through subsoil investigation is very important in generating relevant data inputs for the design and construction of foundations for proposed structures (Nwankwoala and Oborie, 2014).

Because, soils and rocks are very important construction materials used either in their natural state in foundations or excavations or recompacted in dams and embankment (Atkinson, 2007), understanding the engineering properties of soil its crucial to obtaining the strength and economic value (Vitton, 2006). Many studies on the geotechnical properties of marine sediments have been done worldwide due to their roles in the design of offshore foundations (Dan et al., 2007); examples are studies of the coastal mud deposit in Kerala, India (Jiang and Mehta, 1996), the Amazon River, central and 
southern regions of Brazil (Gabioux et al., 2005; Reed et al., 2009), Surinam, Guyana, and Venezuela (Wells and Coleman, 1981; Allison and Lee, 2004; Winterwerpet al., 2007), Greece (Ferentinou et al., 2012), England (Ingliss and Allen, 1957), the Atchafalaya Basin, Southern Louisiana, USA (Jiang and Mehta, 1996; Allison et al., 2000; Fan et al., 2004; Sheremet et al.,2005) and Lagos, Nigeria (Afolayan et al., 2014). Enough attention has not really been given to mud deposits in the coastal regions of Nigeria, especially the coastal regions of the Niger-Delta part of the country and therefore underscores the importance of this study.This study provides general geotechnical information of the Port-Harcourt beach mud as basis for future development of sustainable infrastructure in the area. The knowledge of Port-Harcourt beach soil properties will enable the understanding of the general behavior of coastal soils in the region for recommendation, design and construction of foundations that will be suitable for coastal structures.

\section{MATERIALS AND METHODS}

\section{Study Area}

It is situated at Kolabi creek Port Harcourt, Rivers State. The tourist beach is arguably the most popular beach in Port Harcourt and good for a walk by the sea side and sun bathing. It lies within the geographical coordinates of Latitude $4.752^{\circ} \mathrm{N}$ and $4.753^{\circ} \mathrm{N}$ and between Longitude $7.046^{\circ} \mathrm{E}$ and $7.047^{\circ} \mathrm{E}$. Figure 1 shows the location map of the sampling site. The area chosen for the collection of soil samples for further testing is located along a narrow but long strip by the Port-Harcourt beach. The narrow strip was caused by the reclamation of the beach interior for the purpose of tourism leaving behind a long narrow and undisturbed virgin land along the coast opening into the Amadi creek.

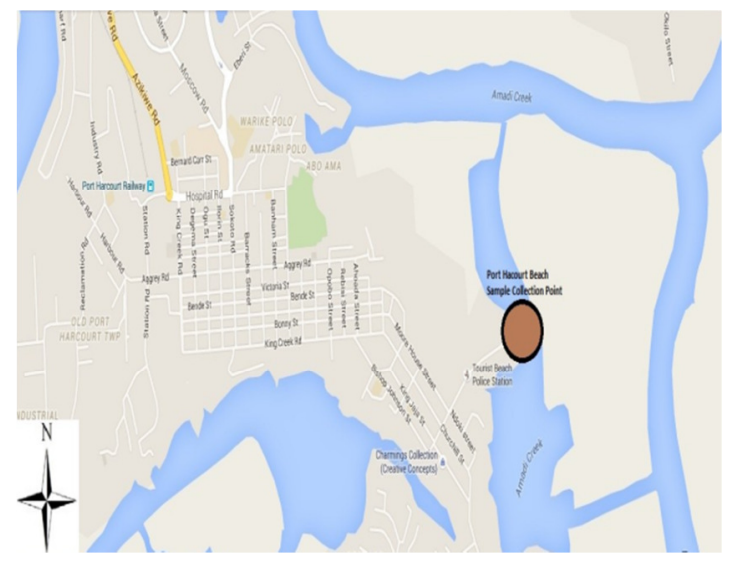

Fig 1. Location Map of Port Harcourt Beach (sampling site)
Collection of soil sample: The investigation comprised mainly five (5) well-spaced geotechnical boreholes with soil sampling executed with hand auger. The borings were taken to a maximum depth of $500 \mathrm{~mm}$ at intervals of $50 \mathrm{~mm}$ between each geotechnical boring. The mud samples were taken with the help of some tourist beach staff. The procedure adopted for boring was opening of the ground by rotating the hand auger clockwise until one gets to the required depth. The first three boreholes (BH1, BH2 and BH3) were located at about 1.83 into $2.44 \mathrm{~m}$ from the coast of the river while the last two geotechnical boreholes were at about $3.35 \mathrm{~m}$ from the coast. It was observed that $\mathrm{BH} 4$ and $\mathrm{BH} 5$ contained more vegetative materials as one drilled deeper into the earth more than the first three borings which were much closer to the coast. The sampling period was during the dry season. After sampling, the mud samples were packed in different polythene bags and were labeled and stored in readiness for laboratory analyses.

Experimental Program: Soil index property and classification tests namely; natural moisture content, specific gravity, particle size analysis and atterberg limits tests were performed on the mud samples. Compaction and California Bearing Ratio (CBR) tests were also performed on the mud samples to determine their strength characteristics. Permeability (constant head) was also performed on the mud samples. All tests were carried out in accordance to the British Standard (BS 1377, 1990).

\section{RESULTS AND DISCUSSION}

Results of Moisture Content Test: Table 1 shows the average moisture content of samples from the different boreholes.

Table 1. Average moisture content and specific gravity of samples collected

\begin{tabular}{cccc}
\hline $\begin{array}{c}\text { Boreholes } \\
\text { Label }\end{array}$ & $\begin{array}{c}\text { Depth of sample } \\
\text { collection from borehole } \\
(\mathrm{mm})\end{array}$ & $\begin{array}{c}\text { Moisture } \\
\text { content } \\
(\%)\end{array}$ & $\begin{array}{c}\text { Specific } \\
\text { Gravity }\end{array}$ \\
\hline BH1 & 300 & 21.32 & 2.5 \\
BH2 & 350 & 22.53 & 2.54 \\
BH3 & 400 & 90.41 & 2.44 \\
BH4 & 450 & 108.74 & 2.48 \\
BH5 & 500 & 112.98 & 2.61 \\
\hline
\end{tabular}

From Table 1, moisture content was found to increase with depth and can be attributed to the sites proximity to water which shows that the water table in the area is close to the surface. Results of the natural moisture content as determined for representative soil samples ranged from $21.3 \%$ to a maximum of $112.98 \%$. These high values obtained indicate that the soil is well saturated and also possess the capacity to allow water 
to permeate through it because of their fine nature. Table 1 shows that $\mathrm{BH} 3$ and $\mathrm{BH} 5$ had the lowest and highest specific gravity values respectively. The average specific gravity of the Port-Harcourt Beach mud was obtained as 2.51 .

Results of Particle Size Distribution test: Particle size distribution test was carried out on the different soil samples. Table 2 shows the particle size analysis and their various soil classifications. Result obtained from the particle size distribution curve (Fig 2) indicates that less than $5 \%$ passed the sieve No. 200 $(0.075 \mathrm{~mm})$ and more than $50 \%$ passed the sieve No. $40(0.425 \mathrm{~mm})$ showing that the soil samples are majorly sandy and according to the Unified Soil Classification System are Poorly Graded Sands (SP) with uniform gradation curve displaying very little or no fines.

Table 2. Particle size analysis

\begin{tabular}{cccccccc}
\hline $\begin{array}{c}\text { Boreholes } \\
\text { Label }\end{array}$ & $\begin{array}{c}\mathrm{D}_{10} \\
(\mathrm{~mm})\end{array}$ & $\begin{array}{c}\mathrm{D}_{30} \\
(\mathrm{~mm})\end{array}$ & $\begin{array}{c}\mathrm{D}_{60} \\
(\mathrm{~mm})\end{array}$ & $\begin{array}{c}\text { Coefficient of } \\
\text { Uniformity } \mathrm{C}_{\mathrm{u}}\end{array}$ & $\begin{array}{c}\text { Coefficient of } \\
\text { Curvature } \mathrm{C}_{\mathrm{c}}\end{array}$ & $\begin{array}{c}\text { USCS } \\
\text { classification }\end{array}$ & $\begin{array}{c}\text { AASHTO } \\
\text { classification }\end{array}$ \\
\hline BH1 & 0.18 & 0.28 & 0.42 & 2.33 & 1.04 & $\mathrm{SP}$ & $\mathrm{A}-3$ \\
BH2 & 0.18 & 0.27 & 0.4 & 2.22 & 1.01 & $\mathrm{SP}$ & $\mathrm{A}-3$ \\
BH3 & 0.19 & 0.29 & 0.52 & 2.74 & 0.85 & $\mathrm{SP}$ & $\mathrm{A}-3$ \\
BH4 & 0.17 & 0.24 & 0.37 & 2.18 & 0.92 & $\mathrm{SP}$ & $\mathrm{A}-3$ \\
BH5 & 0.18 & 0.28 & 0.4 & 2.22 & 1.09 & $\mathrm{SP}$ & $\mathrm{A}-3$ \\
\hline
\end{tabular}

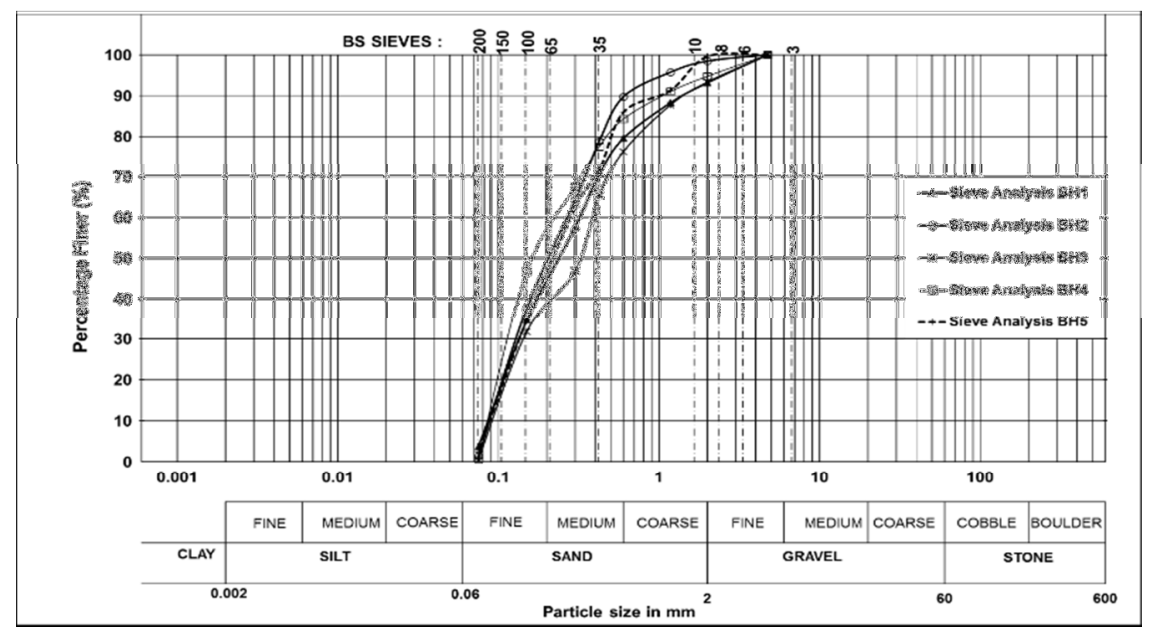

Fig 2. Particle Size Distribution Curve

Table 3. Atterberg Limit values

\begin{tabular}{cccccc}
\hline $\begin{array}{c}\text { Boreholes } \\
\text { Label }\end{array}$ & $\begin{array}{c}\text { Liquid } \\
\text { Limit }(\%)\end{array}$ & $\begin{array}{c}\text { Plastic } \\
\text { Limit }(\%)\end{array}$ & $\begin{array}{c}\text { Plasticity } \\
\text { Index }(\%)\end{array}$ & $\begin{array}{c}\text { Liquidity } \\
\text { Index }\end{array}$ & $\begin{array}{c}\text { Soil classification based on } \\
\text { the plasticity Index }\end{array}$ \\
\hline BH1 & 12.5 & 7 & 5.5 & 2.60 & Low Plastic \\
BH2 & 12.5 & 13 & -0.5 & -19.06 & Non-Plastic \\
BH3 & 11 & 12 & -1 & -78.41 & Non-Plastic \\
BH4 & 14.01 & 9 & 5.01 & 19.91 & Low Plastic \\
BH5 & 15 & 14 & 1 & 98.98 & Low Plastic \\
\hline
\end{tabular}

Atterberg Limit: The particular state of consistency of any particular soil depends primarily upon the amount of water present in the soil-water system thereby making the behavior of soil directly related to the amount of water present. The atterberg limit represents a water content at which the soil changes from one state to another. The values of the atterberg limits of the soil samples are shown in Table 3.

The liquid limit ranges from $11 \%$ to $15 \%$ with an average liquid limit of $13 \%$. The plasticity index which indicates the degree of plasticity of a soil ranges from - $1 \%$ to $5.5 \%$ with an average plasticity index of $2 \%$. From the results obtained, BH1, BH4 and BH5 can be classified as soils with low-plasticity because their plasticity indices were less than 7; while $\mathrm{BH} 2$ and $\mathrm{BH} 3$ are non-plastic soils. The soil samples all met the requirements of the Nigerian General Specifications (FMW\&H, 1997) of not more than $35 \%$ passing sieve No. 200, maximum plasticity index (PI) of $30 \%$ and liquid limit (LL) of a maximum of $50 \%$ for soils used as a subgrade material in road construction

Hydraulic Conductivity: The constant head method was used to determine the hydraulic conductivity of the soil due to its sandy nature. Figure 3 shows the hydraulic conductivities of the five boreholes. The 
hydraulic conductivity values obtained for BH1toBH5 soil samples were $1.5 \times 10^{-1}, 2.4 \times 10^{-1}$, $3.5 \times 10^{-1}, 3.5 \times 10^{-1}$, and $3.5 \times 10^{-1} \mathrm{~cm} / \mathrm{sec}$ respectively. These high hydraulic conductivity values indicate fine to medium sandy soil. Similar results were obtained by Onuoha and Mbazi (1988). The implication of high hydraulic conductivity values is that the aquifer system in the area is prolific (EtuEfeotor, 2000 and Nwankwoala et al., 2008).

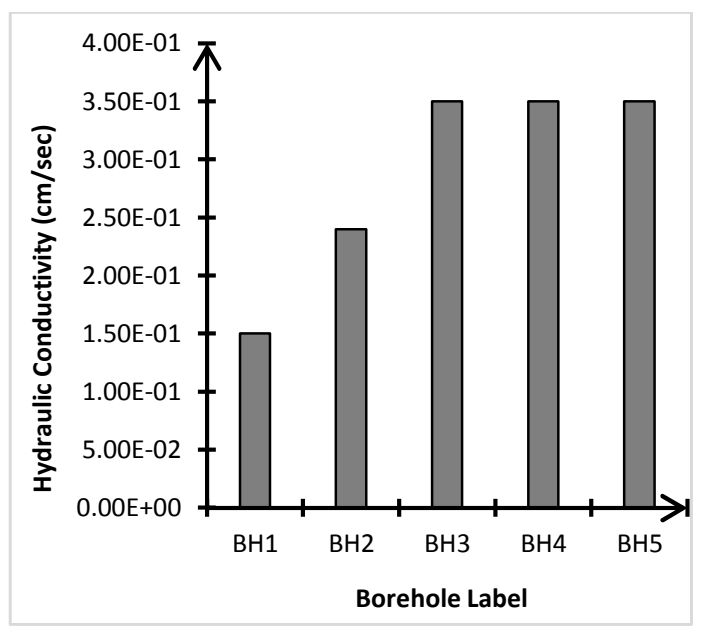

Fig 3. Hydraulic conductivity values of borehole soil samples

Compaction and California bearing ratio tests: Standard proctor compaction test was conducted on the soil samples from the various boreholes. Figure 4 shows the standard proctor compaction test results (maximum dry density $\left[\mathrm{Y}_{\mathrm{dmax}}\right] /$ optimum moisture content $\left[\mathrm{W}_{\text {opt }}\right]$ ) conducted on sampled soils under optimum proctor conditions. The compaction test indicates a good reconstitution of the soil under the necessary conditions to which it is expected to be subjected in the field during the any form of construction.

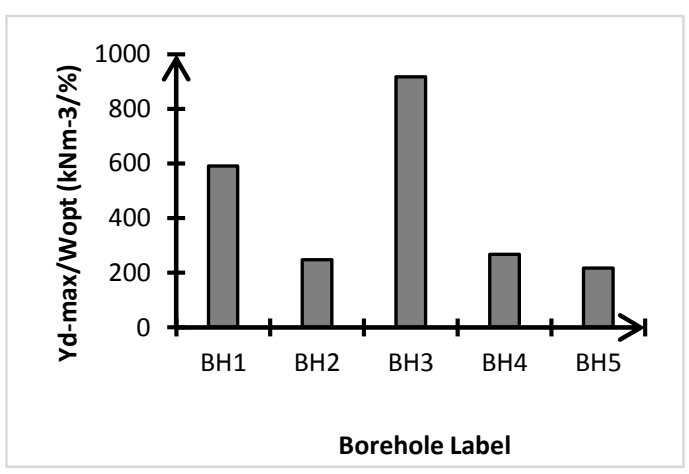

Fig 4. Standard Proctor Compaction test results

Figure 4 shows the ratio of the maximum dry density $\left[\mathrm{Y}_{\mathrm{d}-\mathrm{max}}\right]$ to the optimum moisture content
$\left[\mathrm{W}_{\text {opt }}\right]$ of the soil sampled from the boreholes. From Figure 4, BH3 had the highest ratio of maximum dry density to optimum moisture content while BH5 had the lowest. The compacted samples at their optimum moisture content were then tested for their California Bearing Ratio (CBR) values. Figure 5 shows the soaked CBR test results conducted on the samples at optimum moisture content.

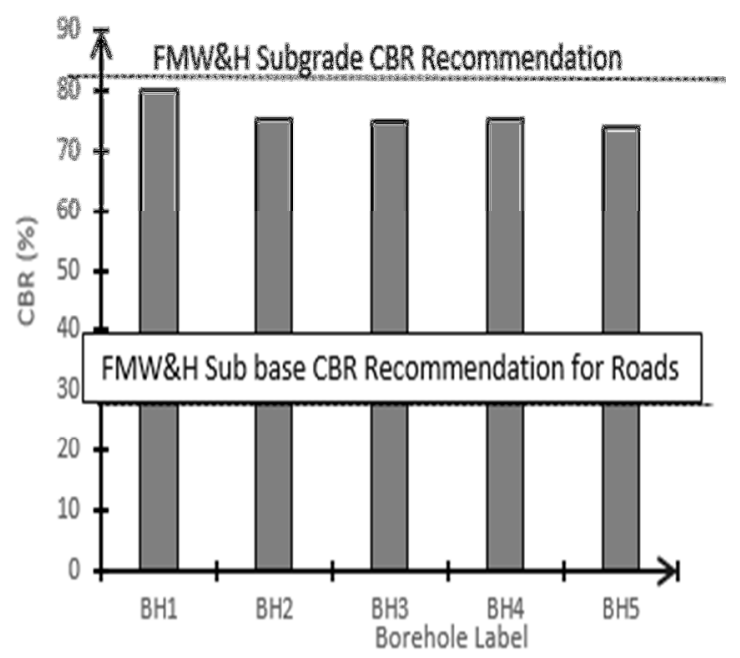

Fig 5. California bearing ratio test results

Figure 5 shows that only BH1 met the $80 \%$ minimum soaked CBR value of subgrade recommended by the Nigerian Federal Ministry of Works and Housing (FMW\&H, 1997). However, all the soil samples met the $30 \%$ required standard for minimum soaked CBR value for sub base in road construction.

Conclusion: This study has shown that the soil in the Port-Harcourt Beach area is underlain predominantly by fine to coarse sands which are poorly graded and implies a relatively high permeability potential. The high proportion of silty clay size fractions in the soil indicates a considerable amount of compressibility. The strength properties of the soil evaluated based on CBR reveals that the soil materials are suitable for subbase and subgrade materials. Results of this study constitute useful preliminary information required for future planning and infrastructural development of Beach Areas in Nigeria.

\section{REFERENCES}

Afolayan, AD; Olumayowa, AA; Oyeronke, AO (2014). Geotechnical Properties of selected Beach Sands in Lagos, Southwestern Nigeria. Geosci. 4 (3):51-53. 
Allison, MA; Kineke, GC; Gordon, ES; Goni, MA (2000). Development and reworking of a seasonal flood deposit on the inner continental shelf off the Atchafalaya River. Continent. Shelf Res. 20(16): 2267-2294.

Allison, MA; Lee, MT (2004). Sediment exchange between Amazon mudbanks and shore fringing mangroves in French Guiana. Mar. Geol. 208:169-190.

Atkinson, J (2007). The Mechanics of Soils. New York: Taylor \& Francis Group.

British Standards Institute (1990). British Standard methods of test for soils for civil engineering purposes: Classification tests. London, BS1377.

Calliari, LJ; Fachin, S (1993). Laguna dos Patos. Influencianos depositoslamiticoscosteiros. Pesquisas 20(1):57-69.

Cao, ZJ; Wang, Y; Li, DQ (2016). Quantification of prior knowledge in geotechnical site characterization. Engineer. Geol. 203:107116.

Clayton, CRI; Matthews, MC; Simons, NE (1995). Site Investigation. Blackwell Science, Cambridge, Mass. USA.

Dan, G; Sultan, N; Savoye, B (2007). The 1979 Nice harbor catastrophe revisited: trigger mechanism inferred from geotechnical measurements and numerical modeling. Mar. Geol. 245:40-64.

Das, BM (2013). Fundamentals of Geotechnical Engineering (Fourth Edition Ed.) California State University, Sacramento, USA. ISBN: 9781111576752.

Dias, CRR; Alves, AML (2009). Geotechnical properties of the Cassino Beach mud. Continent. Shelf Res. 29:589-596.

Dubois, V; Zentar, R; Abriak, NE; Grégoire, P (2011). Fine sediments as a granular source for civil engineering. Eur. J. Environ. Civ. Eng. 15 (2):137-166.

Etu-Efeotor, J (2000). Hydraulic characteristics of the aquifers within the Oligocene-Recent Coastal Plain Sands in parts of Southern Nigeria. Global J Pure Appl. Sci. 6:107-115.
Fan, S; Swift, DJP; Traykovski, P; Bentley, S; Borgeld, JC; Reed, CW; Niedoroda, AW (2004). River flooding, storm resuspension, and event stratigraphy on the northern California shelf: observations compared with simulations. Mar. Geol. 1-4, 17-41.

Federal Ministry of Works and Housing (1997). Nigerian General Specifications for Roads and Bridges. Federal Highway Department 2:145-284.

Ferentinou, M; Hasiotis, T; Sakellariou, M (2012). Application of computational intelligence tools for the analysis of marine geotechnical properties in the head of Zakynthos canyon, Greece. Comp. Geosci. 40:166-174.

Gabioux, M;Vinzon, SB; Paiva, MA (2005). Tidal propagation over fluid mud layers on the Amazon shelf. Continent. Shelf Res. 25:113-125.

Holland, KT; Vinzon, SB; Calliari, LJ (2009). A field study of coastal dynamics on a muddy coast offshore of Cassino Beach, Brazil. Continent. Shelf Res.29:503-514.

Ingliss, CC; Allen, FH (1957). The regimen of the Thames Estuary as affected by currents, salinities and river flow. Proceedings of the Institute of Civil Engineering, 7:827-878.

Jiang, F; Mehta, AJ (1996). Mud banks of the southwest coast of India: wave attenuation.

J. Coast. Res. 12:890-897.

Life (2002). Methods of Management and Re-use of Polluted Sediments, European Project Realized by In Vivo. Agence de l'eau Artois Picardie, Pôle de Compétence des sites et solspollués (Source: Agence de l'eau Artois Picardie http://www.eau-artois-picardie.fr).

Mayne, PW; Christopher, BR; DeJong, J (2002). Subsurface Investigations - Geotechnical Site Characterization No. FHWA NHI-01-031 Federal Highway Administration, U. S. Department of Transportation, Washington D. C.

Nwankwoala, H; Abam, T; Ede, P; Teme, S; Udom, $G$ (2008). Estimates of aquifer hydraulic properties from pumping test data: A case study of Port Harcourt and environs. Wat. Res. J.18:2531. 
Nwankwoala, H; Oborie, E (2014). Geotechnical Investigation and Characterization of Sub- soils in Yenagoa, Bayelsa State, Central Niger Delta, Nigeria .Am. J. Res. Comm. 2.

Reed, AH; Faas, RW; Allison, MA; Calliari, LJ; Holland, KT;O'Reilly, SE; Vaughan, WC; Alves, A (2009). Characterization of a mud deposit offshore of the Patos Lagoon, Southern Brazil. Continent. Shelf Res. 29:597-608.

Sheremet, A; Mehta, AJ; Liu, B; Stone, GW (2005). Wave-sediment interaction on a muddy inner shelf during Hurricane Claudette, Estuarine. Coastal and Shelf Science 63:225-233.

Startrite Maytonand Company (Nig.), Ltd. (2000). Report on Subsurface investigations for the Redemption Ministries, Port Harcourt.

Vitton, S (2006). Introduction to Soil Stabilization. (S. Vitton, Ed.) QEDQ1229, 3.
Wang, Y; Cao, Z J; Li, DQ (2016). Bayesian perspective on geotechnical variability and site characterization. Engineer. Geol. 203:117125.

Wells, JT; Coleman, JM (1981). Physical processes and fine-grained sediment dynamics, coast of Surinam, South-America. J. Sedimentary Petrolog. 51(4):1053-1068.

Winterwerp, JC; de Graaff, RF; Groeneweg, J; Luijendijk, AP (2007). Modeling of wave damping at Guyana mud coast. Coast. Engineer. 54: 249-261.

Youdeowei, PO; Nwankwoala, H O (2011). Studies on sub-soil characteristics of sand deposits in some parts of Bayelsa State, Eastern Niger Delta, Nigeria. J. Soil Sci. Environ. Manage. 2(2):34-38. 